\title{
Analysis of 130 Cases of Pectoralis Major Flap for the Head and Neck Reconstruction
}

\author{
Gil Joon Lee, Chung-Hwan Baek, Han-Sin Jeong, Man Ki Chung, and Young-Ik Son \\ Department of Otorhinolaryngology-Head and Neck Surgery, Samsung Medical Center, \\ Sungkyunkwan University School of Medicine, Seoul, Korea
}

\section{두경부 재건에 시행된 대흥근 피판술 130 예에 대한 분석}

이길준 · 백정환 · 정한신 · 정만기 · 손영익

성균관대학교 의과대학 삼성서울병원 이비인후과학교실

\author{
Received June 17, 2015 \\ Revised September 8, 2015 \\ Accepted September 9, 2015 \\ Address for correspondence \\ Young-Ik Son, MD \\ Department of Otorhinolaryngology- \\ Head and Neck Surgery, \\ Samsung Medical Center, \\ Sungkyunkwan University \\ School of Medicine, \\ 81 Irwon-ro, Gangnam-gu, \\ Seoul 06351, Korea \\ Tel $+82-2-3410-3577$ \\ Fax +82-2-3410-6987 \\ E-mail yison@skku.edu
}

Background and Objectives Pectoralis major flap is the most versatile and reliable flap in the head and neck reconstruction. Owing to the recent development of microsurgical techniques, free flap reconstruction is gaining its popularity as a primary option for the reconstruction of head and neck defects. However, pectoralis major flap is a useful workhorse for the wide variety of situations including heavily irradiated neck, failure of prior reconstruction, and poor recipient vascular status. This study aimed to review our experience of pectoralis major flap surgery and to evaluate its clinical usefulness.

Subjects and Method We reviewed medical records of 113 patients (130 cases) who underwent pectoralis major flap surgery from 1995 to 2014. Indications and complications of pectoralis major flap surgery were evaluated. Association between complication rates and clinical factors were analyzed.

Results Reconstruction of primary surgical defect was the most common indication $(n=81 / 130,62.3 \%)$. Complications developed in 17 cases $(13.1 \%)$. Flap failure was observed in 2 cases $(1.5 \%)$. The length of flap pedicle was closely related with complication rate $(p=0.01)$. However, other factors including flap size, types of flap, radiation history did not influence complication rate.

Conclusion Pectoralis major flap is still a very useful option with a relatively low risk of complication for the head and neck reconstruction even in the era of frequent free flap surgery and heavy irradiation. Korean J Otorhinolaryngol-Head Neck Surg 2016;59(2):133-9

Key Words Head and neck neoplasm - Pectoralis muscles · Pedicled flap · Postoperative complication · Reconstructive surgical procedures.
서 론

구강, 인두, 후두 및 경부를 포함한 등 두경부 영역에 발생 한 질환, 특히 악성 종양으로 인한 광범위한 결손의 경우 기 능적 재건이 필요한 경우가 흔하다. 두경부는 발성, 연하, 호 흡 등 중요한 기능을 담당하는 만큼 구조가 복잡하고 또한 안면을 포함하는 특성상 외형적인 측면을 고려해야 하므로 재건이 기술적으로 단순하지 않고, 가능한 재건 방법의 선택
또한 다양하다.

최근 두경부 재건 영역에서는 미세문합술의 발전으로 유 리 피판술을 이용한 재건이 증가하고 있다. 유리 피판술은 피판의 이동이 자유롭고 도안을 다양하게 할 수 있는 장점이 있지만 술기가 어렵고, 합병증의 빈도가 높으며 수술에 필요 한 장비, 시설의 제한으로 모든 병원에서 부담 없이 진행할 수 없다는 단점이 있다. ${ }^{1)}$ 반면, 국소유경피판(regional pedicled flap)을 이용한 대흥근 피판술은 상대적으로 술기가 쉽고, 실 
패의 빈도가 낮아 안전하게 시행할 수 있으며, 피판으로의 혈 류 공급이 풍부하여 넓은 피부피판, 부피가 두터운 근피판 등 다양한 피판을 거상할 수 있다. 대흥근피판은 회전 반경이 넓고 다양한 도안이 가능하여 두경부의 다양한 결손에 유용 하게 쓰일 수 있다. 또한 한 시야에서 자세 변화 없이 수술이 가능하며 공여부의 일차봉합이 가능한 장점들이 있어 두경부 재건에 많이 사용되고 있다.,3) 대흥근 피판술은 1947년 Pickerel 등이 보고하였고 이후 1979년 Ariyan ${ }^{4}$ 이 경부를 비롯하 여 안면, 두개저, 식도 등 두경부의 다양한 결손 부위 재건에 적용할 수 있음을 보고하면서 두경부 재건에 널리 사용되게 되었고, 현재까지도 두경부 재건에 있어 대표적인 피판술로 쓰 이고 있다. ${ }^{5,6)}$

두경부 재건에서 유리 피판술의 역할이 강조되는 현 상황 에서 다수의 대흥근 피판술 증례를 통해 피판술의 적응증, 피 판의 적용 부위, 치료성적, 합병증 등에 대한 분석을 시행하여 대흥근 피판술의 유용성과 활용 가치를 알아보고자 본 연구 를 진행하였다.

\section{대상 및 방법}

1995 2014년까지 두경부암 진단을 받은 환자 중 대흥근 피 판술을 시행받은 113명(130예)을 대상으로 하였으며, 의무기 록을 후향적으로 분석하였다. 환자의 성별, 진단 시 연령, 병기 등에 대해 조사하였고, 병기 표기는 American Joint Committee on Cancer(AJCC, 7th edition)에 따랐다. 대흥근 피판술 시행 전 받은 치료의 종류에 대해서 분석하였으며 이전 다른 피판술이 시행되었는지 여부에 대해서도 확인하였다.

통계 분석은 SAS ver. 9.2(SAS Institute Inc., Cary, NC, USA) 프로그램을 이용하였고 피어슨 카이 제곱 검정(Pearson's chi-square test), 로지스틱 회귀분석을 포함한 일반선형 모델(Generalized linear model)의 분석방법을 사용하였으며 유의수준은 $p<0.05$ 를 기준으로 하였다.

\section{결 과}

\section{환자 특성 및 수술 적응증 분석}

113명 중 남성이 101명(89.4\%), 여성이 12명(10.6\%)이었으며 평균 연령은 64.1세로 연령 분포는 29 96세였다. 113명의 환 자들의 병기는 stage I 8명(7.1\%), stage II 15명(13.3\%), stage III 14명(12.4\%), stage IV 76명(67.2\%)으로 진행된 암의 비율 이 높았으며 암에 대한 초치료로 수술 단독 치료를 받은 경우 가 58명(51.3\%), 수술을 포함하여 2가지 이상의 치료(방사선 치 료, 항암 치료, 항암방사선 치료)를 받은 경우가 40명(35.4\%),
방사선 단독 치료를 받은 경우가 6명(5.3\%), 항암방사선 동시 치료를 받은 경우가 9 명(8\%)이었다. 대상 환자군 중 방사선 치 료를 받은 환자는 55명(48.7\%), 평균 방사선 조사선량은 6032 (2000 7200) cGy였고 평균 추적 관찰 기간은 31.5(4 116)개월 이었다(Table 1).

130예의 대흥근 피판술 중 병변 제거 후 발생한 수술 부위 결손의 재건을 위한 경우가 81예(62.3\%)로 가장 많았다. 81예 중 초치료 시 대흥근 피판술을 시행한 경우가 49예(37.7\%), 재 발로 인한 구제 수술 시 시행한 경우가 32예(24.6\%)로 조사되 었다. 구인두-피부 누공을 막기 위해 시행된 경우가 29예 (22.3\%), 이전에 시행된 유리 피판술의 실패로 인해 대흥근 피 판술로 재건한 경우가 10예(7.7\%), 대흥근 피판술의 실패로 반 대편 대흥근을 재건에 이용한 경우가 2예(1.5\%)로 이전 피판 술 실패로 인해 재건을 시행한 경우가 12예(9.2\%)로 조사되었 다. 그 외 수술 부위의 감염 6예(4.6\%), 방사선 치료 후 괴사 2 예(1.5\%) 등으로 인해 재건을 시행한 경우가 있었다(Table 2).

원발 병소 및 경부 임파선 절제 등 수술 부위의 결손으로 인해 재건을 시행한 81예를 해부학적 세부 부위에 따라 구분 해 보면 이하선, 악하선 등 침샘을 포함하여 광범위한 경부 절 제가 이루어진 경우가 19예로 가장 많았으며 하인두가 16예,

Table 1. Clinical characteristics of patients underwent pectoralis major flap reconstruction

\begin{tabular}{lc}
\hline \multicolumn{1}{c}{ Clinical characteristics } & All $(\mathrm{n}=113)$ \\
\hline Age [years old, mean (range)] & $64.1(29-96)$ \\
Sex (\%) & $101(89.4)$ \\
Male & $12(10.6)$ \\
Female & \\
Stage (\%) & $8(7.1)$ \\
I & $15(13.3)$ \\
II & $14(12.4)$ \\
III & $76(67.2)$ \\
$\quad$ IV & \\
Initial treatment modalities (\%) & $58(51.3)$ \\
Surgery & $21(18.5)$ \\
Surgery+radiation therapy & $1(0.9)$ \\
Surgery+chemotherapy & $18(16)$ \\
Surgery+chemoradiotherapy & $6(5.3)$ \\
Radiation therapy & $9(8)$ \\
Concurrent chemoradiotherapy & \\
The number of flap surgery (\%) & $96(85)$ \\
Single & $17(15)$ \\
Multiple & $55(48.7 \%)$ \\
Radiation history & $6032(2000-7200)$ \\
Radiation therapy & \\
Radiation dose [cGy, mean (range) & \\
Follow-up [month (range)] & \\
\hline
\end{tabular}


Table 2. Indications of pectoralis major flap reconstruction according to purpose of surgery

\begin{tabular}{lc}
\hline \multicolumn{1}{c}{ Reasons for reconstruction } & No. of cases (\%) \\
\hline Surgical defect reconstruction & $81(62.3 \%)$ \\
Primary reconstruction (initial/salvage) & $69(44 / 25)$ \\
Protection of major vessels (initial/salvage) & $12(5 / 7)$ \\
Previous flap failure & $12(9.2 \%)$ \\
Free flap failure & $10(7.7 \%)$ \\
PMMC failure & $2(1.5 \%)$ \\
Fistula closure & $29(22.3 \%)$ \\
Pharyngocutaneous fistula & 23 \\
Orocutaneous fistula & 6 \\
Wound infection control & $6(4.6 \%)$ \\
Radionecrosis treatment & $2(1.5 \%)$ \\
\hline Total & $130(100 \%)$ \\
\hline PMMC: Pectoralis Maor Musculocutan
\end{tabular}

PMMC: Pectoralis Major Musculocutaneous flap

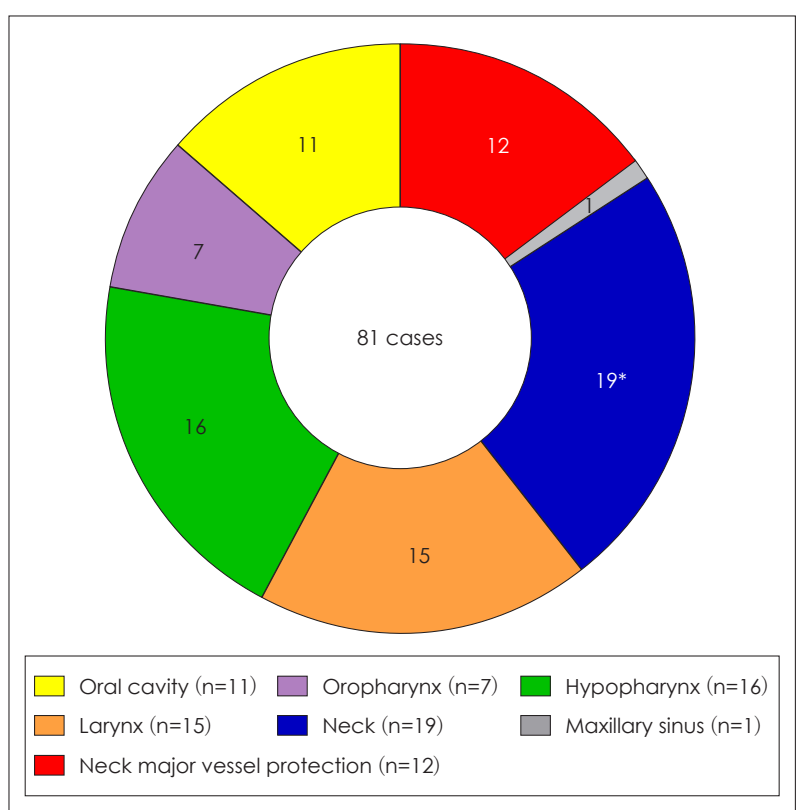

Fig. 1. 81 cases of surgical defects reconstruction according to the anatomic site. *Neck: parotid gland, submandibular gland, thyroid, skin.

후두 및 기관이 15예 순이었다. 경동맥 등 주요 혈관 보호 목 적으로 대흥근피판을 이용한 경우가 12예로 조사되었고 구인 두 11예, 구강 7예, 상악을 재건한 경우가 1예 있었다(Fig. 1).

수술 부위 결손의 재건 목적으로 사용된 81예 중 구제 수술 시 시행된 32예에 대해 조사한 결과, 국소 재발 부위 결손 재 건에 시행된 경우는 9예로 국소 재발 부위는 후두 2예, 하인 두 3예, 설근부 1예, 연구개 1예, 구강설 2예로 조사되었다. 구 역 재발로 인해 경부 재건에 쓰인 경우가 23예로 이 중 7예는 경동맥 등 주요 혈관 보호 목적으로 사용되었다. 구제 수술 시 대흥근 피판술을 시행한 32예의 일차 치료 시 재건술 여부를 조사하였고, 대흥근 피판술과 전외측대퇴 유리 피판술을 동
시에 시행한 경우가 2예, 대흥근 피판술과 공장유리 피판술을 동시에 시행한 경우가 1예, 대흥근 피판술 단독 시행 2예, 전 외측대퇴 유리 피판술 8예, 요골전완 유리피판술 7예, 비골 유 리 피판술 3예, 공장유리 피판술 2예로 총 25예에서 재건술이 시행되었고 7예는 재건술이 시행되지 않았다. 또한 32예 중 25 예에서 일차 치료 당시 방사선 치료를 시행하였고 평균 조사량 은 5840(2000 7000) cGy로 조사되었다.

\section{대흥근 피판술의 합병증}

대흥근 피판술로 인한 합병증은 총 17예(13.1\%)에서 발생하 였다. 피판 실패, 누공 형성(fistula formation)과 수술 부위 벌 어짐(wound dehiscence) 등이 각각 4예(3.1\%)로 나타났고, 재 건 부위 혈종 및 감염이 2예씩(1.5\%) 있었으며, 육아종 형성이 1 예로 조사되었다 $(0.76 \%)$. 누공 형성은 서로 다른 두 공간 사 이의 교통이 발생한 경우로 정의하였고, 수술 부위 벌어짐은 피부 및 연부 조직의 벌어짐 현상이 발생하였으나, 두 공간 사 이의 교통 형성은 되지 않은 상태로 정의하였다. 피판 실패는 전피판 실패와 부분피판 실패로 구분하였고 전피판 실패는 피 판의 $50 \%$ 이상에서 괴사가 나타난 경우로 정의하였으며 2예 (1.5\%)에서 발생하였고 2예 모두 반대측 대흥근피판을 이용하 여 재건하였다. $50 \%$ 미만의 부분적인 피판 괴사를 보인 경우 를 부분피판 실패로 정의하였고 피부피판의 부분괴사가 2예 (1.5\%) 있었으며 1예에 대해서는 전피층 피부이식(full thickness skin graft)을 시행하였고, 1예는 보존적 치료를 하며 2차 치유를 유도하였다. 누공 형성은 인두-피부 간 3예(2.3\%), 기 관-식도 간 1 예(0.76\%)있었으며, 3 예의 인두-피부 간의 누공 형성에 중 2예에서 창상 청소술 및 일차 봉합이 시행되었고 1 예에서 광배근(lattismus dorsi muscle)을 이용한 재건술이 시 행되었다. 기관-식도 간 누공에 대해서는 전외측대퇴근(anterolateral thigh muscle)을 이용한 유리피판 재건술이 시행되 었다. 수술 부위 벌어짐이 발생한 4예(3.1\%)에서는 모두 창상 청소술 후 일차봉합을 시행하였다. 창상 감염이 2예(1.5\%) 있 었으며 2예 모두 창상 청소술 및 항생제 정맥투여의 보존적 치료를 시행하였다. 그 외 수술 후 출혈로 인한 혈종 2예 (1.5\%), 육아종 형성 1예(0.76\%)의 합병증이 있었으며, 혈종에 대해서는 창상 개방 하 혈종 제거술 및 지혈을 시행하였고, 육 아종은 외래 치료실에서 부분 마취 하 육아종 제거술을 시행 하였다(Table 3).

\section{대흉근 피판술과 합병증 간의 관련 요인}

대흥근 피판술 후 합병증의 관련 요인을 찾기 위해 연령, 성 별, 병기, 방사선 조사력, 피판의 크기, 피판의 형태, 피판의 이 동거리 등과 합병증 발생 간의 연관성을 조사하였다. 연령은 
Table 3. Complications of pectoralis major flap reconstruction

\begin{tabular}{lcl}
\hline \multicolumn{1}{c}{ Complication } & No. of cases $(\%)$ & Management \\
\hline PMMC failure $(>50 \%)$ & $2(1.5)$ & Revision PMMC \\
Partial necrosis $(<50 \%)$ & $2(1.5)$ & $\begin{array}{l}\text { Full thickness skin graft } \\
\text { Secondary healing }\end{array}$ \\
$\begin{array}{l}\text { Suture line dehiscence } \\
\text { Wound infection }\end{array}$ & $4(3.1)$ & $\begin{array}{l}\text { Primary closure } \\
\text { Intravenous antibiotics }\end{array}$ \\
Fistula & $2(1.5)$ & Lattismus dorsi flap \\
$\quad$ Pharyngocutenous fistula & $3(2.3)$ & Primary closure \\
$\quad$ Tracheoesophageal fistula & & Anterolateral thigh free flap \\
Hematoma & $1(0.76)$ & Hematoma evacuation \\
Granulation & $2(1.5)$ & Granulation removal
\end{tabular}

PMMC: Pectoralis Major Musculocutaneous flap

Table 4. Association between complications and timing of RT

\begin{tabular}{|c|c|c|}
\hline & RT before PMMC & RT after PMMC \\
\hline No. of patients & 36 & 19 \\
\hline RT dose (cGy) & $5947(2000-7200)$ & $6045(5400-6800)$ \\
\hline No. of complications & 4 & 2 \\
\hline Complication (n) & $\begin{array}{l}\text { Partial necrosis (1) } \\
\text { Wound infection (1) } \\
\text { Suture line dehiscence (1) } \\
\text { Hematoma (1) }\end{array}$ & $\begin{array}{l}\text { Partial necrosis (1) } \\
\text { Suture line dehiscence (1) }\end{array}$ \\
\hline p-value & & \\
\hline
\end{tabular}

RT: radiation therapy, PMMC: Pectoralis Major Musculocutaneous flap

평균 64.1세로 연령과 합병증 발생 간의 통계적으로 유의한 차 이는 보이지 않았으며 $(p=0.97)$ 성별은 남성이 101명, 여성이 12 명으로 남성이 많았으며 성별과 합병증 발생 간에도 통계적 으로 유의한 차이를 보이지 않았다 $(p=0.51)$. 암의 병기와 합병 증 간에서는 전체 17 예의 합병증 중 1 기에서 1 예, 2 기에서 2예, 3 기에서 4예, 4 기에서 10예로 전반적으로 암의 병기가 진행될 수록 합병증의 발생 빈도가 높아졌으나, 통계학적으로 유의한 차이를 보이지는 않았다 $(p=0.56)$. 전체 113 명의 환자 중 55 명 에서 방사선 조사력이 있었으며, 그중 대흥근 피판술 시행 전 방사선 치료를 받은 환자가 36 명, 대흥근 피판술 이후 방사선 치료를 받은 환자가 19 명이었다. 방사선 치료를 받은 55 명의 평균 조사량은 6032(2000 7200) cGy였으며 총 6명에서 합병 증이 발생하였다. 대흥근 피판술 이전에 방사선 치료를 받은 36 명의 평균 조사량은 5947(2000 7200) cGy, 방사선 치료 이후 대흥근 피판술을 받은 19명의 평균 조사량은 6045(5400 6800) $\mathrm{cGy}$ 로 각각 4명, 2명에서 합병증이 발생하였다. 방사선 치료 가 대흥근 피판술의 합병증 발생에 미치는 영향을 조사하기 위해 대흥근 피판술 전 방사선 치료를 받은 경우와 대흥근 피 판술 후 방사선 치료를 받은 경우 합병증 발생 빈도의 차이를 비교하였고, 대흥근 피판술 이전에 방사선 치료를 받은 경우 합병증의 발생 빈도가 높았으나, 대흥근 피판술 이후에 방사
선 치료를 받은 군과 비교하여 합병증 발생 빈도는 통계학적 으로 유의한 차이는 없었고( $p=0.94)$ (Table 4), 방사선 치료를 받은 군과 받지 않은 군을 비교한 결과에서도 합병증 발생 간 의 통계적으로 유의한 차이를 보이지 않았다 $(p=0.53)$. 대흥근 피판의 크기와 합병증 발생 간의 관계를 조사하였고, 피판의 크기는 가로 $\times$ 세로의 면적을 기준으로 하였으며 평균 크기는 $35.4\left(12\right.$ 120) $\mathrm{cm}^{2}$ 였다. 피판의 크기가 커질수록 합병증이 발 생할 확률이 1.09 배 상승하는 것으로 나타났으나 통계학적으로 유의한 차이는 없었다(95\% confidence interval; 0.978 1.214). 대흥근피판의 형태는 거상하는 피부피판의 면적이 근피판보 다 작은 근육형(muscle paddle), 피부피판과 근피판의 면적이 같은 완전형(full paddle), 근피판의 보호를 받지 못하는 혈관 경을 가진 진도서형(island paddle), 혈관경을 분리시켜 유리피 판 형태로 사용하는 유리피판형(free paddle) 등 4가지로 분류 하였고 ${ }^{7)}$ 근육형 122예, 진도서형 6예, 유리피판형 1예, 완전형 1예였으며, 근육형에서 15예(11.5\%)의 합병증이 발생하였고, 진도서형과 유리피판형에서 각각 1 예(0.8\%)의 합병증이 발생 하였다. 피판의 형태에 따른 합병증 발생 간의 차이는 통계학 적으로 의미 있는 결과를 보이지 않았다 $(p=0.07)$. 피판의 이동 거리와 합병증 발생 간의 관계를 조사하기 위해 피판의 이동 거리에 따라 3 구역으로 나누고 각 구역 간의 합병증 발생 빈도 


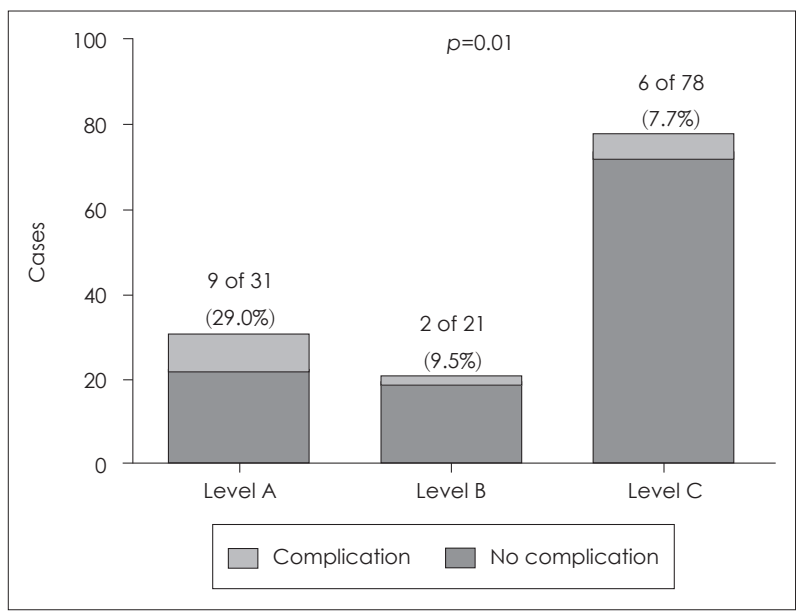

Fig. 2. Relationship between the length of pedicle and complication rate. Complications were more frequently occurred in Level $A$ (above oropharynx) than in Level C (beneath oropharynx) group $(p=0.01)$

를 파악하였다. 인두를 기준으로 구강, 상악, 경구개, 이하선 등 을 포함하는 인두 상부(above oropharynx), 편도, 설기저부, 연 구개 등을 포함하는 인두부(oropharynx), 하인두, 후두 등을 포함하는 인두 하부(beneath oropharynx)로 구분하였고 총 130예 중 인두 상부가 31예(23.6\%), 인두부 21예(16.2\%), 인두 하부가 78예(60\%)였다. 인두 상부 재건에 사용된 대흥근피판 의 평균 크기는 $32.2 \mathrm{~cm}^{2}$ 였으며, 근육형이 27예, 진도서형이 4 예로 피판의 이동거리가 멀어 상대적으로 진도서형 피판이 많 이 사용되었다. 인두 상부에서의 합병증 발생은 9예로 전피판 실패 1예, 봉합 부위 벌어짐 및 혈종이 각각 2예로 조사되었다. 인두부에 사용된 피판의 평균 크기는 $35.3 \mathrm{~cm}^{2}$ 였으며, 21예 모두 근육형 피판이 사용되었고, 합병증은 2예로 전피판 실패 와 부분피판 실패가 각각 1 예씩 있었다. 인두 하부에 쓰인 피 판의 평균 크기는 $40.0 \mathrm{~cm}^{2}$ 였으며 피판의 형태는 근육형이 74 예, 진도서형 2예, 유리피판형, 완전형이 각각 1예였다. 합병증 은 6예로 부분피판 실패 1예, 인두-피부 누공 1예, 기관-식도 누공 1예, 수술 부위 열개 2예, 감염 1예로 조사되었다. 피판의 이동거리에 따라 구분한 구역에 따른 합병증 발생 간의 차이 는 통계학적으로 의미 있는 것으로 나타났다( $p=0.01)(F i g .2)$.

\section{고 찰}

대흥근피판은 혈관이 풍부하고 경부와 해부학적으로 근접 해 있어 넓은 영역의 결손을 안전하게 다양한 목적으로 재건 할 수 있는 장점이 있다. 본 연구에서도 이러한 대흥근피판의 장점들을 확인할 수 있었다. 구인두, 후두, 하인두, 피부 등 다 양한 결손 부위의 재건이 가능하였고, $12 \mathrm{~cm}^{2}$ 의 작은 결손에 서 $120 \mathrm{~cm}^{2}$ 의 큰 결손까지 재건이 가능하였다. 유리 피판술 재
건이 실패한 경우 좋은 대안이 되었고 방사선 치료의 부작용 으로 누공, 괴사 등 합병증이 발생한 경우, 경동맥 노출로 인한 파열의 예방을 위한 경우 등 다양한 목적으로 활용되었다. ${ }^{8,9)}$

대흥근 피판술이 실패한 경우는 전체 130예 중 4예로 피판 술의 성공률은 $97 \%$ 로 비교적 안전한 재건술임을 확인할 수 있었다. 실패한 4예 중 2예는 부분적인 피부 괴사였고 재건술 을 다시 시행해야 할 정도로 광범위한 피판 괴사가 발생한 경 우는 2예로 전체의 $1.5 \%$ 였다. 대흥근 피판술 후 합병증은 17 예에서 발생하였고 전체의 $13.1 \%$ 에서 나타났다. 이 중 국소피 판이나 유리피판 등 다시 재건술이 필요한 경우는 대흥근 피 판술 2예, 광배근 피판술 1예, 전외측대퇴 유리 피판술 1예로 총 4예로 조사되었다.

대흥근 피판술과 합병증의 발생 사이의 관련 요인들을 파 악하고자 하였다. 병기가 진행될수록 환자의 전신 상태가 좋 지 않을 것이고 재건 범위가 넓어질 것으로 예상할 수 있으므 로 병기를 관련 인자 중 하나로 고려하였다. 방사선 조사의 병 력이 있고 조사량이 많을수록 재건 부위의 혈류 공급이나 조 직 상태가 좋지 않을 것으로 가정하여 방사선 조사력도 관련 요인으로 분석하였다. 피판 인자로는 피판의 크기, 형태, 이동 거리를 고려하였다. 피판의 크기가 커질수록 혈류 공급을 담 당하는 범위가 넓어지며, 피판이 도서형이나 유리피판형인 경 우 실패 확률이 증가할 것이라고 예상할 수 있어 합병증 관련 인자로 고려하였다. 마지막으로 피판의 이동거리가 길어진다 는 것은 혈관 및 피판에 긴장력이 크게 부과됨을 의미하므로 합병증 관련 인자로 고려하였다. 본 연구에서는 합병증과 관 련이 있을 것이라고 예상한 관련 인자 중 피판의 이동거리에 따른 차이가 의미 있는 관련 인자로 파악되었고, 나머지 인자 는 의미 있는 관련성이 확인되지는 않았다. 특히 방사선 치료력 은 합병증 발생과 연관성이 있을 것으로 예상하였고, Corten 등 ${ }^{10)}$ 다른 연구들의 보고에 따르면 방사선 치료력은 대흥근 피 판술 후 합병증 발생의 주요 요인으로 조사되었으나 본 연구 에서는 방사선 치료에 따른 합병증 발생에 통계적으로 유의한 차이가 없는 것으로 조사되었다. 방사선 치료 유무와 합병증 발생 $(p=0.53)$, 대흥근 피판술 전후의 방사선 치료력과 합병증 발생 $(p=0.94)$ 간을 조사하였고, 방사선 치료가 대흥근 피판술 후 합병증 발생에 영향을 주는 요인은 아닌 것으로 나타났다.

피판의 이동거리를 증가시키기 위해서는 피판의 회전이 용 이해야 하며 혈관경이 꼬이거나 많은 압력이 가해지지 않도록 해야 한다. 따라서 피판 거상 시 혈관경 주변 조직의 박리가 많 아지고 필요 시 쇄골 주변의 근육, 연부조직을 일부 제거하기 도 한다. 이 과정에서 혈관경이 손상을 받을 가능성이 높아지 고, 피판의 이동거리가 증가할수록 천공지(perforator)에 의존 하는 피판의 부분이 증가하므로 피판의 이동거리가 짧은 인두 
하부 영역보다 인두 상부 영역에서 피판의 불안정성이 높아져 합병증 비율이 더 높게 나타나는 것으로 생각된다. 기존의 대 흥근 피판술 후 합병증에 관한 연구를 살펴보면 전반적 괴사 를 보인 피판 실패는 $1.5 \sim 4 \%$, 부분 괴사가 발생한 경우는 6.6 18.6\%, 수술 부위의 벌어짐은 9.5 19\%, 누공 형성은 9 28.6\%, 수술 부위 감염은 10.5 31\%로 조사되었고, ${ }^{11-16)}$ 본 연구와 비교하여 보면 합병증의 종류는 대체적으로 유사함을 보였으나 합병증의 빈도는 전반적으로 본 연구에서 낮게 나타 남을 확인하였다. 재건술을 다시 시행하여야 할 정도의 심한 합병증인 전피판 괴사로 인한 피판 실패는 본 연구를 포함하 여 대부분의 연구에서 $5 \%$ 미만으로 비슷하게 조사되었다.

본 기관에서는 결손 부위와 크기에 따라 전외측대퇴유리피 판(anterolateral thigh free flap), 공장유리피판(jejunal free flap) 등과 대흥근피판을 동시에 적용해 재건하는 경우가 적 지 않다. 구강이나 구인두의 점막 결손과 더불어 경부 결손이 커서 하나의 피판으로 내, 외측면을 동시에 재건하기 어려운 14예에서는 전외측대퇴근피판과 대흥근피판을 함께 이용하였 다. 후두 및 하인두 적출술 후 재건 시 설기저부와 상부 식도 사이에 발생하는 튜브 형태의 결손을 보인 6예에서는 공장유 리피판으로 구강-식도 간을 재건하고 대흥근피판으로 덮어주 는 술식을 동시에 사용하였다. 결손 부위가 크거나 결손 부위 의 형태가 복잡한 경우 무리한 대흥근피판의 적용보다 대흥근 피판과 더불어 다른 피판을 동시에 적용하는 것이 사강 $(\mathrm{dead}$ space), 타액 유출(saliva leakage), 봉합 부위 벌어짐, 감염, 누 공 형성의 합병증을 감소시켜 더 안전할 것으로 생각된다.

본 연구는 단일 기관에서 시행된 대흥근 피판술을 분석한 것으로 술기와 술자의 다양성, 환자군의 중증도, 분포 등의 측 면에서 다기관 연구를 통한 분석 혹은 체계적 문헌 고찰을 통 한 메타분석 등과 같은 대표성을 갖기 어려운 점이 있다. 또한 심혈관 질환, 당뇨병 등 대상 환자들의 전신 상태를 반영할 수 있는 기저 질환의 유무가 합병증 발생에 영향을 주는지 여부 ${ }^{17)}$ 그리고 흡연, 음주 등이 요인이 합병증 발생에 미치는 영향에 대한 조사가 이루어지지 못한 점은 본 연구의 한계점으로 지 적할 수 있다.

2000년대 이후 현미경, 미세수술 장비의 발전 등으로 유리 피판술을 이용한 재건이 증가하고 있고, 유리 피판술의 성공 률은 기관마다 차이는 있으나, 높게는 $95 \%$ 이상까지 보고하 는 등 많은 발전을 거듭하고 있다. ${ }^{18)}$ 하지만 유리 피판술은 술 기가 어렵고 수술 시간이 길며 상대적으로 공여부의 이환율 과 피판 생존율이 국소 피판술보다 낮다. 또한 충분한 장비, 시설을 갖추고 있는 기관에서만 시행 가능하므로 제약이 따 른다. 수술 후 1 2주 정도 혈전, 출혈, 혈종 등의 발생 여부를 관찰하면서 피판을 감시해야 하며, 피판이 실패하는 경우 재
수술을 통해 다시 재건해야 하는 위험 부담이 따른다. 환자의 전신 상태나 혈관의 상태가 좋지 못한 경우 피판이 실패할 확 률이 높아지고 특히 방사선 치료를 받은 경우 피판 실패는 4 배 이상 높아진다는 보고도 있다. ${ }^{19)}$ 본 연구를 통해 대훙근 피 판술은 두경부 결손 재건에 다양한 목적으로 사용 가능하며 합병증의 비율도 낮아 두경부 재건에 유용하게 쓰일 수 있음 을 확인하였다. 구강, 구인두, 인후두 및 하인두, 상악 등 다양 한 부위, 다양한 크기의 결손에 쓰일 수 있으며 이전에 방사선 치료를 받았거나 전신 상태 등의 이유로 유리 피판술을 시행 하기 어려운 경우, 경동맥 등 주요 혈관이 취약한 경우, 수술 적 치료, 방사선 치료 등의 치료 과정에서 합병증이 발생한 경 우 합병증을 해결하기 위한 경우 등 다양한 목적을 위해서 대 흥근 피판술을 시행하였다. 대흥근 피판술로 인한 합병증 발 생률은 낮으나 구강 상부로 피판이 이동해야 하는 경우 합병 증 발생 위험이 증가하므로 혈관경을 다루는 과정에서 주의를 기울어야 하며, 본 연구에서 관련성이 확인되지는 않았으나 여러 연구에서 합병증 관련 인자로 지적하고 있는 방사선 치 료를 받은 병력, 당뇨병, 심혈관 질환 등 기저질환의 유무 등을 동시에 고려해야 한다. 최근 두경부 재건 분야에서 유리 피판 술이 중요한 위치를 차지하고 있으나 유리 피판술의 제한점과 국소 피판술로서의 장점을 고려하였을 때 대흥근 피판술은 여전히 두경부 재건술의 선택 시 우선적으로 고려할 수 있는 효용 가치가 높은 재건술이다.

\section{REFERENCES}

1) Urken ML, Weinberg H, Buchbinder D, Moscoso JF, Lawson W, Catalano PJ, et al. Microvascular free flaps in head and neck reconstruction. Report of 200 cases and review of complications. Arch Otolaryngol Head Neck Surg 1994;120(6):633-40.

2) Chepeha DB, Annich G, Pynnonen MA, Beck J, Wolf GT, Teknos $\mathrm{TN}$, et al. Pectoralis major myocutaneous flap vs revascularized free tissue transfer: complications, gastrostomy tube dependence, and hospitalization. Arch Otolaryngol Head Neck Surg 2004;130(2):181-6.

3) Koh KS, Eom JS, Kirk I, Kim SY, Nam S. Pectoralis major musculocutaneous flap in oropharyngeal reconstruction: revisited. Plast Reconstr Surg 2006;118(5):1145-9; discussion 1150.

4) Ariyan $\mathrm{S}$. The pectoralis major myocutaneous flap. A versatile flap for reconstruction in the head and neck. Plast Reconstr Surg 1979;63(1): 73-81.

5) Baek SM, Lawson W, Biller HF. An analysis of 133 pectoralis major myocutaneous flaps. Plast Reconstr Surg 1982;69(3):460-9.

6) Shah JP, Haribhakti V, Loree TR, Sutaria P. Complications of the pectoralis major myocutaneous flap in head and neck reconstruction. Am J Surg 1990;160(4):352-5.

7) Choi EC, Choi JY, Kang SS. True island pectoralis major myocutaneous flap: its advantages. Korean J Otolaryngol-Head Neck Surg 2000;43 (2):201-7.

8) Kroll SS, Goepfert H, Jones M, Guillamondegui O, Schusterman M. Analysis of complications in 168 pectoralis major myocutaneous flaps used for head and neck reconstruction. Ann Plast Surg 1990;25(2):93-7.

9) Mehta S, Sarkar S, Kavarana N, Bhathena H, Mehta A. Complications of the pectoralis major myocutaneous flap in the oral cavity: a 
prospective evaluation of 220 cases. Plast Reconstr Surg 1996;98(1):31-7.

10) Corten EM, Schellekens PP, Hage JJ, Kon M. Clinical outcome after pedicled segmental pectoralis major island flaps for head and neck reconstruction. Ann Plast Surg 2009;63(3):292-6.

11) Vartanian JG, Carvalho AL, Carvalho SM, Mizobe L, Magrin J, Kowalski LP. Pectoralis major and other myofascial/myocutaneous flaps in head and neck cancer reconstruction: experience with 437 cases at a single institution. Head Neck 2004;26(12):1018-23.

12) Milenović A, Virag M, Uglesić V, Aljinović-Ratković N. The pectoralis major flap in head and neck reconstruction: first 500 patients. J Craniomaxillofac Surg 2006;34(6):340-3.

13) Pinto FR, Malena CR, Vanni CM, Capelli Fde A, Matos LL, Kanda JL. Pectoralis major myocutaneous flaps for head and neck reconstruction: factors influencing occurrences of complications and the final outcome. Sao Paulo Med J 2010;128(6):336-41

14) McLean JN, Carlson GW, Losken A. The pectoralis major myocutaneous flap revisited: a reliable technique for head and neck reconstruction. Ann Plast Surg 2010;64(5):570-3.
15) Sharma S, Murty PS, Hazarika P, Nayak DR, Sharma S. The indications and complications of pectoralis major myocutaneous flap reconstruction in head and neck surgery-our experience. Indian $\mathrm{J}$ Otolaryngol Head Neck Surg 1998;50(4):362-7.

16) You YS, Chung CH, Chang YJ, Kim KH, Jung SW, Rho YS. Analysis of 120 pectoralis major flaps for head and neck reconstruction. Arch Plast Surg 2012;39(5):522-7.

17) Hashimoto I, Takaku M, Matsuo S, Abe Y, Harada H, Nagae H, et al. Risk factors for complications after reconstructive surgery for sternal wound infection. Arch Plast Surg 2014;41(3):253-7.

18) Genden EM, Rinaldo A, Suárez C, Wei WI, Bradley PJ, Ferlito A. Complications of free flap transfers for head and neck reconstruction following cancer resection. Oral Oncol 2004;40(10):979-84.

19) Lee $S$, Thiele $C$. Factors associated with free flap complications after head and neck reconstruction and the molecular basis of fibrotic tissue rearrangement in preirradiated soft tissue. J Oral Maxillofac Surg 2010;68(9):2169-78. 